\title{
The Travel Guide as a Tool for Promoting the Tourism Potential of a Region (As Exemplified by Lipetsk Oblast)
}

\section{Irina Polyakova}

Ph.D. in Philology, Associate Professor, Department of Tourism and Hotel Industry High Professional School Yelets State Bunin University; iepolakova@mail.ru

\section{Raisa Ivanova}

Ph.D. in Philology, Associate Professor, Department of Tourism and Hotel Industry High Professional School Yelets State Bunin University; elrmiv@mail.ru

\section{Olga Skrobotova}

Ph.D. in Philology, Associate Professor, Department of Tourism and Hotel Industry High Professional School Yelets State Bunin University; skrolga48@mail.ru

Doi:10.5901/mjss.2015.v6n6s5p331

\section{Abstract}

\begin{abstract}
The article addresses the specifics and principles of creating a region guidebook as one of the main marketing tools for promoting the tourism potential of an area. It concentrates on the most important aspects of the structure and contents of this kind of edition, aspects that are relevant in the light of the preferences of a contemporary user - amateur tourist as a specific and fast-growing category. Lipetsk Oblast of the Russian Federation with a tourism potential which requires active study and popularization in order to develop domestic and inbound tourism has been chosen as a base for developing the requirements for the travel guide. At present in Lipetsk there is no full, rationally structured and convenient printed travel guide that would give maximally comprehensive information both for the amateur and organized tourist.
\end{abstract}

Keywords: travel guide, promotion of tourism product, amateur tourism, tourism resources, tourism potential.

\section{Introduction}

Under conditions of the current economic crisis it is expedient to redirect the Russian tourism from outbound to domestic and inbound tourism, which has been the aim of the state policy with respect to tourism for several years. Accordingly, the federal target program, "Development of domestic and inbound tourism in the Russian Federation (2011-2018)" was developed and approved (by the RF Government Decree of August 2, 2011 № 644). Relevant in this context is the formation and promotion of regional tourism product (Dzhandzhugazova, 2011). One of the promising regions of Russia which may provide a competitive product in the tourist market is Lipetsk Oblast. In the region, there exist and develop special economic zones of tourist-recreational type of the regional level, "Yelets" and "Zadonshchina", as well as a tourism and recreation cluster (TRC) "Yelets" and an auto touring cluster (ATC) "Zadonshchina"; from 2013, an ATC "Oranienburg" (the town of Chaplygin, Chaplyginskiy district) is being formed, and from 2015, new tourism and recreation clusters are being developed, "Shukhovskiy" (Dankovskiy district) and "Dobry" (Dobrovskiy district). In addition, each Oblast district has unique tourism potential for creating a tourism product that will be in demand. This potential, despite the tourism development program operating in the region (in particular, the recently approved state program, "Development of Culture and Tourism" of 29 November 2013) is currently insufficiently studied. Issues of regional tourism and of tourism potential are addressed in the papers by R.M. Ivanova (Ivanova, 2008), A.N. Seleznev (Seleznev, 2008). However, there is no comprehensive and system study of tourism potential of the region. A lot of sites in Lipetsk Oblast which constitute a powerful potential and may be significant attractions are not included in tourist itineraries due to poor knowledge of them. Some of the interesting attractions remain unknown to potential tourists. Thus, an important part of the tourism resources is ignored. Today, there are a lot of methods of promotion of tourism attractions, from the relatively cheap ones (distribution of printed materials in the places of tourists' stay and at tourism exhibitions, and others) to creating costly portals and services on the Internet. A guidebook is still a fairly popular way to deliver information to 
tourists. Creation of a modern travel guide requires taking into consideration tourists' needs, the practice of creating similar editions, the characteristics of the information environment in which the travel guide will exist; as well as the necessity to promote a particular region. The guidebook created with the tourist's needs in mind can become an effective tool of promotion.

The development of a travel guide to Lipetsk Oblast is an important and necessary step towards the successful promotion of the tourism product of the region in the tourism market (Zamyatin \& Zamyatina, 2007). Its creation is based on a detailed study of the tourism potential of the Oblast districts, which implies the identification and description of the tourism attractions (focusing mainly on cultural and educational type of tourism) and of the tourism infrastructure facilities. At present in Lipetsk there is no full, rationally structured and convenient guidebook that would give maximally comprehensive information for the tourist.

\section{Theory and Methods}

\subsection{Methods}

The research is focused on identifying a rational system of the principles of creating a travel guide to the region, namely on defining a clear-cut rational structure, composition and specificity of the content in accordance with its functional goals, and in this connection on creating the methods for selecting information to be included in the guidebook. Depending on these aims, the research methods include the following:

- terminology analysis method for defining more accurately and distinguishing between the concepts, "travel guide' and "travel catalogue", "amateur tourism" and "organized tourism";

- the method of structural analysis and the related structural and functional method, classification methods, and systematization method necessary for studying the structure and classifications of modern printed travel guides, as well as for developing the methods of collecting information about the attractions to be included in the travel guide to the region;

- the source analysis method used in the study of scientific papers on the subject of the article and in the study of the versions of the existing tourist guides to regions of the Russian Federation, including Lipetsk Oblast

- the method of comparative analysis required in identifying the strengths and weaknesses of the considered travel guides

\subsection{Theoretical aspects of the study of the specificity of the travel guide}

The Big Encyclopedic Dictionary (BES) gives the following definition: "A travel guide is a reference book containing information about the country, city, tourist itinerary, historical and artistic monuments, etc." (Big Encyclopedic Dictionary). However, in our opinion, to understand the specificity of the travel guide, one cannot rely solely on that definition, as it does not reflect the essence characteristic and the main function of this kind of edition implicit in the term morphology, namely that the travel guide is designed to "guide", point the way, the route. This does not allow us to distinguish between similar genre types such as the travel guide and the travel catalog, which the above definition actually suits. In addition, there are inaccuracies in the classification of travel guides. Thus, depending on how the users are transported, two kinds of guides are sometimes distinguished: itinerary travel guides ("point of interest" in such guidebooks are shown in a sequence determined by the itinerary) and reference guidebooks (order of movement of tourists is not indicated). In the second case we deal not with a guide but with a catalog or a reference book.

In this context, more appropriate is the definition of a travel guide given in the national standard of the Russian Federation GOST 7.60-2003 "SIBID. Editions. The main types. Terms and Definitions": A reference book, that contains information about some geographic or cultural-educational institution (activity), arranged in the order, easy to follow or "(GOST 7.60-2003). This definition is correct in the sense that with preparation of a travel guide to the region, it allows us to focus on one of the main tasks of the edition - to build a rational itinerary for the tourist. In this regard, the guide must have such characteristics as clearly structured material and expedient arrangement of the information about attractions, taking into account the orientation to the itinerary of the amateur tourist.

Thus, the main principle of creating a travel guide must be orientation to the needs of the tourist, first of all, the amateur one. Amateur (in other terms, independent, free-weeling) tourism, in contrast to the organized one, is "traveling and hiking, including the active forms of transportation, arranged by the tourists themselves, without turning to organizations or individual entrepreneurs providing tourism services" (GOST R 54601-2011). The amateur tourist forms the itinerary by himself, without resorting to the services of tour operators or travel agents: he/she buys a ticket to travel, 
finds a hotel, and selects destinations and excursions, actively using maps and guidebooks. Currently, the number of such tourists is increasing, which is due to many factors: the low cost of trips, simplified reservation systems for booking hotels and buying tickets, the growing number of "literate" travelers who without agents and overpayments are able to find the necessary information for creating their tour, etc. As to the internal tourism, the amateur tourists usually travel by car (auto tourism). In this situation it is especially important for them to have a travel guide with reliable and relevant information not only about the sights of the area, but about accommodation, public catering facilities, tourist information centers, gas stations and others. And it is desirable that the information in the travel guide be grouped, basing on the priority needs of this category of tourists: at first, information on available accommodation and catering facilities, on transport accessibility, etc. should be provided and then, about the sights.

Depending on tourists' needs there are different classifications of travel guides. By the specifics of the material, there are guides to the countries of the world, to particular countries, to particular regions; the thematic guides are a special category. By genre, travel guides are divided into advertising-reference and reference-advertizing editions "represented by handouts, booklets and brochures (a self-guide, a free guide, a brief guide); and author's guides, which are informational - advertising and reference - encyclopedia editions" (a tourist handbook, a souvenir guide, a guide book, a complete guide)(Filatova, 2012, p. 79).

Among all classifications of travel guides, classification by the form of information presentation is of the greatest interest. In accordance with this feature, there are printed, electronic, audio and video travel guides. The audio guide is used primarily when familiarizing oneself with the museum exhibit, or on an excursion without a guide (guide-interpreter), whereas the printed, electronic and video guides are usually used to explore the tourist area (of the country or region) and navigate through it. Video guides are convenient for studying at home before the trip.

Among the tourist information materials listed above, electronic (internet, GPS) guides are gaining the increasing popularity, first of all among young people. This is certainly connected with the convenience and speed of sorting of and searching for the required information. Therefore, when creating a travel guide, it is necessary to focus on the needs of modern tourists. "Guides, that can be stored in the mobile phone and that will contain all the necessary information (brief information about the city, set of itineraries with pictures and a brief description of objects; information on public catering facilities: canteens, cafes, bars, restaurants; emergency numbers, hospitals telephone numbers, and many others) will make tourists more mobile and increase the attractiveness of Russian cities" (Malyshev, 2013, pp. 84-87). However, this does not mean that the printed travel guide as a type must and may go out of use forever.

\section{Results and Discussion}

The printed travel guide is the most ancient kind preferred by many modern travelers too. Now it is of secondary importance compared with the electronic one, but its necessity cannot be doubted, since it remains one of the most important information means of advertising a tourist area, a necessary element of its image (Antonova, 2006; Rutsinskaya 2013). The abundance and unlimited use of the Internet information, in particular, of advertising "dissolves" the user in it, distracts his/her attention and therefore reduces its marketing efficiency; whereas the printed edition of the travel guide is almost a unique phenomenon, and at least it attracts attention. Thus, the printed version can and should complement the GPS-guide. But in addition, it should maximally meet the user's need for convenience, so it should look somewhat differently from its predecessors. It should be a pleasure to hold it in your hands; it should be bright and colorful, light, convenient, compact, having the "readable" print size (should not impede reading). In addition, a modern printed guide should be interactive, which in particular, can be achieved by giving the information in a concise, easily perceived form, as well as by supplying links to Internet resources, as well as hyperlinks just as it is done in the electronic guide. The system of popular hyperlinks is quite acceptable and understandable in the printed form, and it is only slightly more difficult to use.

It is convenient to interact with the user in the printed travel guide through static infographics. Currently, infographics is a trendy and common way of presenting information; it is widely used on the Internet, on television and in the printed text. Infographics is a kind of modern graphic design, a visual and artistic presentation of the material with the help of words, pictures, diagrams, geometrical figures; it implies delivering information to the reader in a capacious, laconic manner.. In the guidebook, infographics is not an innovation: a map of tourist destinations, a rubricator - all these are kinds of infographics. However, an important task in creating a guide will be to approach the electronic version, which implies even clearer, even more accessible, laconic and convenient delivery of the material providing for the interactivity of the edition. The solution of this problem is fascilitated by a wide use of a system of signs, diagrams, images and tables; a graphical presention of information; a colorful, eye-catching design; emotional colors; simplification, etc., while maintaining the internal integrity of the transmitted information. Thus, thanks to the correct use of infographics it is 
possible to solve a number of problems at a time: to reduce the overall volume of the guide, to simplify delivery of information to the recipient, to make it convenient, to create an exemplary, illustrative publication through visualization of material, to make it similar to the electronic version.

So, the printed travel guide must have a convenient (in terms of search speed and clarity) rubricator and navigation. All these requirements are based on the demands of the modern tourist who expects the speed and ease-ofuse of the information resource, as well as satisfaction from the outcome. However, the printed guide to the region should not be a duplicate of the electronic one. It may be different in the completeness of the material resources of the area (to be more concise, schematic or, on the contrary, full), but in any case, it may be an addition to the electronic (Internet) version.

Speaking of the visual expression of the travel guide, it is necessary to dwell on the requirements for photographs of the attractions placed in the publication. Photos of attractions are perhaps, the most important component of the travel guide, which is often the main criterion for the tourist to choose tourism attractions, accommodation and other tourism resources. In this regard, there must be a sufficient number of photo illustrations in the guide. They must be original (not previously used in other publications, that is, plagiarism is excluded), of high quality, colored, vivid, excluding gloomy background, and presenting the object at the best camera angle.

One of the significant drawbacks of printed travel guides to regions, as A.A. Sokolova rightly believes, is incomplete information due to "the orientation of the developers and authors to a mass audience, to meeting the need for entertainment and other activities not related to the consumption of useful information", as well as a shift in emphasis and misrepresentation of information (Sokolova, 2011, p. 163). Indeed, it is improper to distort information about significant attractions of a tourism area or not to make it available at all in the guide. All this makes the guidebook an unreliable source and leads to the impoverishment of the image of a destination, directly affecting the amount of tourism demand. However, the completeness of the information in the travel guide is rather relative. Giving details of each destination attraction one can make the guide, in the first place, "dimensionless", overwhelmed with information, massive, and therefore inconvenient to use; and secondly, the attractions become less interesting for an excursion visit; thirdly, the guide in this case will go beyond the genre and turn into an encyclopedia of attractions (resources). Thus, when creating a travel guide, it is important to remember that the information placed in it, depends on the tourist interest. In this regard, it is rational to specify the information only about the resources that can enjoy tourist demand. Of course, the degree of tourist interest in this case is a subjective value, and it is possible to calculate it only figuratively, given certain parameters. For example, architectural monuments have indicators such as age, current condition, a certain degree of attractiveness, accessibility, location in relation to other excursion objects, unique character, historical significance (the monuments of federal and regional level), and so forth. All these criteria, of course, affect the level of the tourist demand for the attraction. Thus, an architectural monument of regional importance that does not possess a high degree of uniqueness and attractiveness, is located at a very great distance from other objects of the territory and is inaccessible for seeing (it is not possible to come up to it on foot) will be less important for the tourist (as was pointed out above, the criteria are relative, since much depends on the individual preferences of the tourist; therefore, the basis is the needs of the "average" (mass) tourist).

Today, travel guides to the regions of the Russian Federation, including Lipetsk Oblast, meet the above-listed requirements to the structure and contents only partially.

After examining a series of regional guides (most of these publications are promotional materials, so there are no conventional output data: "Green Guide. Eco travel guide to Kaluga Oblast", issue № 2, 2013; "Lipetsk Oblast. The most comprehensive guide" (2014) ; "Travel guide to Leningrad Oblast" (under the. ed. of Birzhakov M.B., 2007); "Guide to Ivanovo and Ivanovo Oblast" (published by Ajax-Press, 2014); "A short guide to Kostroma Oblast"' (Bychkov, 2010); Guides of "Petit Fyute" series (Ryazan, Orenburg, Novosibirsk, Tyumen, Omsk, Irkutsk Oblasts, and others) we came to the conclusion that the most complete in terms of this approach is a guide to Kaluga Oblast "Green Guide. Eco travel guide to Kaluga Oblast", issue № 2, 2013). However, it does not cover all the resources of a destination, as it is topical: the publication is focused solely on environmental kind of tourism in the area. Nevertheless, the strong points of this guide are a full rubricator and convenient navigation, interactivity, a system of hyperlinks, a clearly seen composition, abundance of illustrations, colorfulness and, of course, compactness. Of the major weaknesses, the lack of connection with the itinerary of the amateur tourist should be mentioned. The attractions are not located on the 'itinerary' principle; therefore the guide in this case does not "indicate the path", i.e. it does not fulfill its primary function of the genre, which again is a result of gaps in the terminology and contradicts the definition given in the GOST 7.60-2003 (see above).

However, to this criterion - basic, in our opinion - none of the considered travel guides corresponds (several excursion itineraries in the guidebooks of Leningrad and Ivanovo Oblasts are an indicative exception to the general rule, however, this does not make them full travel guides). 
The compact guidebook of the "Petit Fyute" series and the guidebook to Kostroma Oblast have a convenient rubricator, but the publications are oversaturated with reference and encyclopedic information (historical information, detailed descriptions of the attractions, and so on.), which, based on the interests of tourists, should be presented in the guide very concisely. This information is more suitable for a tourism catalogue.

Finally, the travel guide to Lipetsk Oblast (2014), which requires a more detailed consideration, being the object of our study, has more drawbacks than positive features.

Strengths: beautiful, colorful edition of reference and encyclopedic nature. It may be a good souvenir.

Weaknesses:

- a large format. Size: $15 / 21 \mathrm{~cm}$, volume: 399 pages. It is a very big book, weighing about a kilogram. It rather resembles an encyclopedic publication about outstanding attractions. It may be very inconvenient for the tourist. This book may be of interest only for the residents of the area as a souvenir edition about their native land;

- poor rubricator;

- information about navigating through areas is given only on page 44, not in the index, making it difficult to find the information;

- It is hard to read the navigation, as the areas of Lipetsk Oblast are indistinctly colored: eighteen areas are of pastel colours, difficult to distinguish. (four regions are light blue or of similar colors, other four districts are light green, etc.) Thus, the search for the desired object by this navigator is almost impossible;

- it is hard to perceive the structure of the guide, presented in the "Contents" (for example, highlighted are the sections such as "Architecture", "Road Infrastructure", "History of Lipetsk Land", "Great People", "Navigating the Regions", "Celebrations and Traditions in Lipetsk Land" which are separated from the largest section, "Lipetsk Oblast. Region by region" where logically, the information contained in the above sections should be placed);

- positioning of the guide as "the most complete," which has been repeatedly refuted in the Internet blogs and in the press, can rightly be doubted (see BlogoMedia);

- the sources of the information are unreliable (ibid.);

- there is no connection with tourist itineraries, the described monuments are presented outside the general historical and cultural context of the area of regions and towns and cities of Lipetsk Oblast;

- there is no clear algorithm of selecting attractions to be included in the guide;

- the edition abounds in a number of errors (factual errors, the ambiguity of stylistic structures, syntax errors, and so on.).

Thus, the presence of this edition does not solve the problem of the promotion of tourism product of Lipetsk Oblast; therefore the need to create a full travel guide remains. Therefore, our future work on studying and popularization of the tourism potential of Lipetsk Oblast will consist in developing the methods of collecting the information on tourism attractions for the travel guide to the region. From the general information about Lipetsk Oblast as a tourism area, about the availability of various tourism resources, as well as taking into account the tourist needs, we will determine the methods for collecting information about Lipetsk Oblast tourism attractions that are of interest both for organized and amateur tourists.

\section{Conclusion}

Such are the requirements that the region travel guide must meet, and that will be applied in creating a new printed travel guide to Lipetsk Oblast.

The development of tourism in the region implies that most of the Oblast districts, cities and towns will be included in the priority lines of the inbound tourism. This is to a large extent promoted by a detailed study and popularization of the districts' tourism resources. The examination of the tourism potential of Lipetsk Oblast followed by reflecting its outcomes in the travel guide will contribute to the promotion of the regional tourism product. The travel guide must contain maximally full information about a tourism destination in a laconic and convenient form. For this purpose it is expedient to include in it a correctly built rubricator referring the user to the sought-for section. The rubricator is necessary first of all because of the abundance of information, as it requires gradation of the material by heads related to particular kinds of tourism, tourism attractions, etc. Visual expression and interactivity of the travel guide must determine its significant aspect.

Summing up, the printed travel guide is a most important and integral means of promotion of Lipetsk Oblast in the 
tourism market; therefore, correct composition, contents and design are functionally necessary for this kind of edition. Besides, as the tourism resources of this territory have not been systematized, and no catalogs have been issued, creation of the travel guide becomes particularly important. Thus, its development will be the final stage of our study of the tourism potential of the region.

\section{Acknowledgements}

The publication has been prepared under the research project \#15-32-01319 supported by RHSF.

\section{References}

Antonova, Z.V. (2006). Stanovleniye i razvitiye putevoditelya kak vida izdaniya [The formation and development of a travel guidebook as a kind of edition]. M.: MGOU.

Bol'shoy entsyklopedicheskiy slovar' [Big encyclopedic dictionary]. Retrived from: http://dic.academic.ru/dic.nsf/enc3p/247914

Dzhandzhugazova, E.A. (2006). Marketing turistskikh territoriy [Marketing of tourism areas]. Uchebnoye posobiye. Seriya: Vyssheye professional'noye obrazovaniye. M.: Academia, 112.

Filatova, N.V. (2012). Zhanrovoye prostranstvo turisticheskogo diskursa [Genre space of a tourism discourse]. Vestnik Moskovskogo gosudarstvennogo gumanitarnogo universiteta im. M.A.Sholokhova. Filologicheskiye nauki, Vyp. 2, 76-82.

GOST 7.60-2003 "SIBID. Izdaniya. Osnovnye vidy. Terminy i opredeleniya [Editions. Mainkinds. Terms and definitions.] Retrieved from http://ohranatruda.ru/ot_biblio/normativ/data_normativ/42/42116/

GOST P 54601-2011: Turistskiye uslugi. Bezopasnost' aktivnykh vidov turizma. Obshchiye polozheniya. [Tourism services.Safety of active kinds of tourism. General provisions.] Retrieved from http://docs.cntd.ru/document/gost-r-54601-2011

Ivanova, R.M. (2008). Potentsial razvitiya turizma v Lipetskoy oblasti [The development potential of tourism in Lipetsk Oblast]. Turizm: resursy, tehnologii, obrazovaniye. Yelets: EGU imeni I.A .Bunina, 32-37.

Malyshev, S.V. (2013). Sovremennye tekhnicheskiye sredstva predstavleniya informatsii na turistskikh obyektakh i marshrutakh [Current technical aids for presenting information on tourism sites and itineraries]. Turizm - faktor ustoichivogo razvitiya regiona: sbornik statey regional'noy nauchno-prakticheskoy konferentsii s mezhdunarodnym uchastiyem. Vyp.3. Nizhegorodskiy gos. arkhitekturn.-stroit. un-t; redkol.: N.N.Girovka [i dr.]. N.Novgorod: NNGASU, 84-87.

Rutsinskaya, I.I. (2013). Putevoditel' kak fenomen massovoy kul'tury. Obrazy rossiyskikh regionov v provintsial'nykh putevoditelyakh vtoroy poloviny XIX- nachala XX v. [The travel guide as a phenomenon of mass culture. Images of Russian regions in provincial travel guidebooks of the second half of the XIX - the beginning of the XX centuries]. M.: Lnard, 228.

Seleznev, A.N. (2008). Voprosy klassifikatsii turistskikh resursov [Issues of the classification of tourism resources]. Turizm: resursy, tekhnologii, obrazovzniye. Yelets: EGU imeni I.A.Bunina, 68-71.

Sokolova, A.A. (2011). Geograficheskoye soiderzhaniye obraza turistskoy territotii i problema yego dostovernogo otobrazheniya pri prodvozhenii turistskikh resursov [Geographical content of a tourism area image and the problem of its authentic representation in promoting tourism resources]. Vestnik Leningradskogo gosudarstvennogo universiteta im. A.S. Pushkina, Vyp. 3, tom 6, 155165.

Zamyatin, D., Zamyatina, N. (2007). Imidzhevye resursy territorii: identifikatsiya, otsenka, razrabotka i podgotovka k prodvizheniyu imidzha [Image resources of an area: identification, assessment, development and preparation for the promotion of the image]. Gumanitarnaya geografiya: nauchn. i kul'turno-prosvetitel'skiy al'manakh. Vyp.4. M.: Institut naslediya, 227-250. 


\title{
The Influence of Alcohol Addiction on Cognitive Functions of the Representatives of Indigenous Population of Siberia
}

\author{
Nikolay Bokhan \\ Doctor of Medical Sciences, Professor, Corresponding Member of RAS, Honored Scientist of the RF, Director of Mental Health \\ Research Institute, Head of the Addictive Conditions Department, 4 Aleutskaya Str., Tomsk, Russia, 634014 \\ redo@mail.tomsknet.ru

\section{Anastasiya Peshkovskaya} \\ Junior Researcher of the Addictive Conditions Department, Mental Health Research Institute, \\ 4 Aleutskaya Str., Tomsk, Russia, 634014; peshkovskaya@sibmail.com
}

\begin{abstract}
Anna Mandel
Doctor of Medical Sciences, Professor, Leading Researcher of the Addictive Conditions Department Mental Health Research Institute, 4 Aleutskaya Str., Tomsk, Russia, 634014; anna-mandel@mail.ru

Irina Badyrgy

Chief physician, State budget-funded healthcare institution of the RT Republican drug abuse clinic 29/1 Kalinina Str., Kyzyl, Republic of Tyva; rndtuva@mail.ru

Ekaterina Mikhalickaya

Postgraduate student at the Mental Health Research Institute, 4 Aleutskaya Str., Tomsk, Russia, 634014 uzen63@mail.ru
\end{abstract}

\section{Doi:10.5901/mjss.2015.v6n6s5p337}

Abstract

\begin{abstract}
As a model for studying the ethnic and cultural aspects of alcohol abuse problem the narcological situation in the Republic of Tyva (Russia) which is relevant for Siberian region. Clinical and psychological examination of 155 alcohol addicted registered in the Republican drug abuse clinic (Kyzyl) was carried out, with 91 people of them being Tuvinian nationality, and 64 people Russians. In order to study the particularities of thinking and intellectual integrity of the alcohol abusers, the "Pictograms" technique was used. The content of the tested ones' memory was estimated using the "Learning 10 words" technique. The cognitive particularities of representatives of Tuvinian and Russian ethnos with alcohol addiction are described. The particularities of cognitive disorders of alcohol abusers have been determined that consist in reduced memory productivity, consistency of associative connections. The relation between graphic characteristics of drawings of the alcohol abusers which act as indicators of organic lesions of brain and the severity of clinical signs of alcoholic abuse is stated. In representatives of the Tuvinian ethnos, alcohol addiction damages the ability to speak in complex abstract terms and reduces the productivity of memorizing to a larger extent as compared to Russians, which confirms greater vulnerability of the indigenous ethnos to the effect of alcohol.
\end{abstract}

Keywords: alcohol addiction, cognitive disorders, thinking, memory, ethnic distinctions.

\section{Introduction}

The relevance of clinical and psychological studies of the problem of alcohol abuse is determined by the acute character of the narcological situation in the Eastern region of the Russian Federation and a high frequency of medical and social consequences of alcohol abuse (Koshkina, 2011; Bokhan et al., 2013; WHO, 2014). The history of Western industrial civilization spreading to the East and the consequences of acculturation stress in the indigenous population confirm the significant influence of ethnic and cultural factors on the context of formation of clinical and psychological particularities of 